\title{
Geotherm and a rheological profile for the central Fennoscandian lithosphere
}

Kukkonen, I.T., and Peltonen, P.

Geological Survey of Finland, P.O. Box 96, FIN-02151 Espoo Finland

(ilmo.kukkonen@gsf.fi; petri.peltonen@gsf.fi)

We compare thermobarometry data from 21 kimberlite-hosted mantle xenoliths with a 2dimensional numerical thermal model of the lithosphere to provide a integrated geotherm for the central Fennoscandian Shield in eastern Finland. Kimberlites, which contain mantle xenoliths, intrude the outernmost edge of the late Archaean craton nucleus adjacent to Palaeoproterozoic mobile belt. Detailed petrology of the mantle xenoliths, which include both garnet and garnet-spinel facies peridotites, pyroxenites, and eclogites, are described in detail elsewhere in this volume (Peltonen et al., 1998). Most of the studied xenoliths suit well for thermobarometry because all phases are unzoned and because mineral analyses (both SIMS and $\mathrm{Nd} / \mathrm{Sr}$ isotopes) imply that garnets and clinopyroxenes were in mutual chemical and isotopic equilibrium at the time of their detachment from the lithospheric mantle. In the results obtained equilibrium is manifested by small $\left(<100^{\circ} \mathrm{C}\right)$ range of temperatures calculated by eleven distinct calibrations. Thermobarometry results (iteratively solved T[Krogh, 1988] - P[Brey and Köhler, 1990]) are in agreement with a conductive geotherm corresponding to a surface heat flow density (HFD) of $36 \mathrm{mWm}^{-2}$ (Fig. 1). Garnet peridotites yield pressures which indicate depths between $170-230 \mathrm{~km}$. Importantly, they all belong to the "coarse" subtype, widely believed to represent the subcontinental lithospheric mantle (SCLM), while none are akin to the "sheared" type of possible derivation from the uppermost asthenosphere, implying that petrological lithosphere is over $200 \mathrm{~km}$ thick in the study area consistent with the absence of inflection in the geotherm. This xenolith-based geotherm turned out to be in close agreement with the earlier, independently determined, numerical 2-D conductive model for the present lithospheric temperatures (Kukkonen and Jõeleht, 1996). In this study, we have slightly revised this conductive model by using constant mantle heat flow density as the lower boundary condition in the mantle $\left(12 \mathrm{mWm}^{-2}\right.$ at $250 \mathrm{~km}$ under the kimberlite area). Further, heat production values in the model were corrected for the decrease in the intensity of radioactive decay of $\mathrm{U}, \mathrm{Th}$, and $\mathrm{K}$ during the past $500 \mathrm{Ma}$ in order to obtain more accurate geotherm at the time of the kimberlite emplacement (Fig. 1).

The revised geotherm was used to calculate the rheological profile of the lithosphere by determining the relative magnitudes of frictional and creep strengths of different layers of the lithosphere (e.g. Ranalli and Murphy, 1987). The rheological thickness of the lithosphere at the site of the kimberlites is estimated to be $130-185 \mathrm{~km}$ depending on the applied value of the creep strength of mantle rocks. Importantly, most of the PT-data from the xenoliths cluster around 170-180 km which may be an indication of a structural (strength) boundary at this depth which favoured the "sampling" by the kimberlite magma. The seismic lithosphere thickness values correlate best with the base of the rheological lithosphere. Because some texturally similar ("coarse") xenoliths, however, imply also much greater depths (up to $230 \mathrm{~km}$ ), the rheological lithosphere is substantially thinner than the petrological and thermal lithosphere. As a whole, the lithosphere-asthenosphere relations in central parts of the Fennoscandian Shield can be considered as a system of rheologically controlled plate thickness of about $180 \mathrm{~km}$, underlain by thermal boundary layer extending to at least $230 \mathrm{~km}$, and transported together with the rheological lithosphere in plate tectonic movements. 


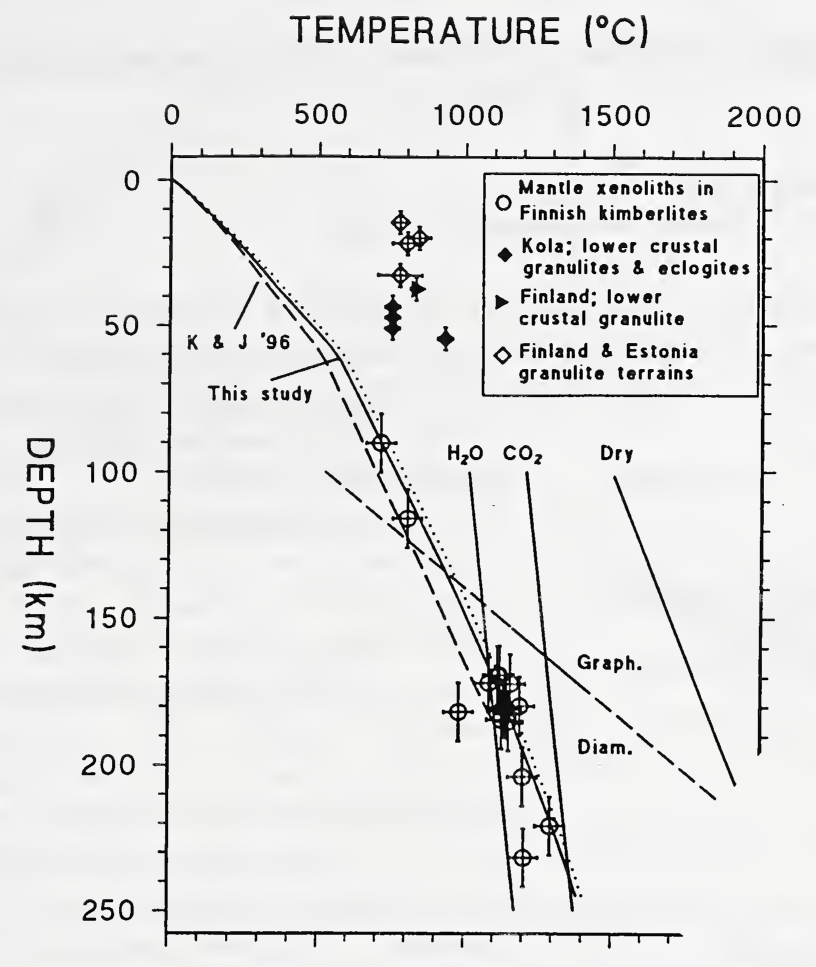

Fig. 1. Comparison of the geothermobarometry and the calculated geotherms. Solid line is the geotherm representing the present situation (this study), the dotted line corresponds to conditions $500 \mathrm{Ma}$ ago, and the broken line is the geotherm according to the 2-D conductive model of Kukkonen and Jõeleht (1996).

\section{References}

Brey, G., and Köhler, T., 1990, Geothermobarometry in four-phase lherzolites II: New thermobarometers and practical assessment of existing thermobarometers. J. Petrol., v. 31, p. 1353-1378.

Krogh, E.J., 1988, The garnet-clinopyroxene iron-magnesium geothermometer - a reinterpretation of existing experimental data. Contrib. Mineral. Petrol., v. 99, p. 44-48.

Kukkonen, I.T., and Jõeleht, A., 1996, Geothermal modelling of the lithosphere in the central Baltic Shield and its southern slope. Tectonophysics, v. 255, p. 24-45.

Kukkonen, I.T., and Peltonen, P., 1998, Xenolith controlled geotherm for the central Fennoscandian Shield: Implications for lithosphere - asthenosphere relations. Tectonophysics, submitted.

Peltonen, P., Huhma, H., Tyni, M., and Shimizu, N., 1998, Garnet peridotite xenoliths from kimberlites of Finland: nature of the continental mantle at Archaean craton - Palaeproterozoic mobile belt transition. This volume.

Ranalli, G., and Murphy, D.C., 1987, Rheological stratification of the lithosphere. Tectonophysics, v. 132, p. 281-295. 